\title{
EFFECT OF LEADERSHIP AND JOB SATISFACTION ON PERFORMANCE WITH COMMITMENT MEDIATION (IN PT ALAM KAYU SAKTI SEMARANG)
}

\author{
Soegihartono
}

Universitas Semarang

Diterima: Mei 2019, Disetujui: Juni 2019, Dipublikasikan: Juli 2019

\begin{abstract}
The purpose of the research is to test and analyze whether there is an influence of leadership and job satisfaction on the performance of employees of PT. Alam Kayu Sakti (PT. ALKA) Semarang by mediating organizational commitment. As the object of this research are permanent employees of PT. Alam Kayu Sakti (PT. ALKA) Semarang with a sample of 109 employees as respondents. The question used has been tested for validity by factor analysis and reliability with Cronbach alpha and the instruments are valid and reliable or worthy of being used as a research tool. The results of the analysis can be summarized as follows:

This study can prove leadership has a positive effect on organizational commitment. This is in accordance with his theory Bass (1990). This study can prove job satisfaction has a positive effect on organizational commitment. This is according to Johlke's (2000) study. This research can prove leadership has a positive effect on performance. This is in accordance with his theory Bass (1990). This study can prove job satisfaction has a positive effect on performance. This is in accordance with his theory Robins (1996). This study proves organizational commitment has a positive effect on performance. This is in accordance with the study of Johlke et al (2000). This study does not prove that organizational commitment mediates on the influence of leadership on performance. This is in accordance with Tri Murdoko's research (2007). This study does not prove that organizational commitment mediates on the effect of job satisfaction on performance. This is in accordance with Yustiani's research, Utai Dian (2005)
\end{abstract}

Keywords: leadership, job satisfaction, organizational commitment and performance 


\begin{abstract}
ABSTRAK
Tujuan dari penelitian ini adalah untuk menguji dan menganalisis apakah ada pengaruh kepemimpinan dan kepuasan kerja terhadap kinerja karyawan PT. Alam Kayu Sakti (PT. ALKA) Semarang dengan memediasi komitmen organisasi. Sebagai objek penelitian ini adalah karyawan tetap PT. Alam Kayu Sakti (PT. ALKA) Semarang dengan sampel sebanyak 109 karyawan sebagai responden. Pertanyaan yang digunakan telah diuji validitasnya dengan analisis faktor dan reliabilitas dengan Cronbach alpha dan instrumen yang valid dan dapat diandalkan atau layak digunakan sebagai alat penelitian. Hasil analisis dapat diringkas sebagai berikut:

Penelitian ini dapat membuktikan kepemimpinan memiliki efek positif pada komitmen organisasi. Ini sesuai dengan teorinya Bass (1990). Penelitian ini dapat membuktikan kepuasan kerja berpengaruh positif terhadap komitmen organisasi. Ini menurut penelitian Johlke (2000). Penelitian ini dapat membuktikan kepemimpinan memiliki pengaruh positif terhadap kinerja. Ini sesuai dengan teorinya Bass (1990). Penelitian ini dapat membuktikan kepuasan kerja berpengaruh positif terhadap kinerja. Ini sesuai dengan teorinya Robins (1996). Penelitian ini membuktikan komitmen organisasi berpengaruh positif terhadap kinerja. Ini sesuai dengan penelitian Johlke et al (2000). Studi ini tidak membuktikan bahwa komitmen organisasi memediasi pengaruh kepemimpinan terhadap kinerja. Ini sesuai dengan penelitian Tri Murdoko (2007). Studi ini tidak membuktikan bahwa komitmen organisasi memediasi pengaruh kepuasan kerja terhadap kinerja. Ini sesuai dengan penelitian Yustiani, Utai Dian (2005)
\end{abstract}

Kata kunci: kepemimpinan, kepuasan kerja, komitmen dan kinerja organisasi

\title{
INTRODUCTION
}

\section{Background}

Changes in environment and technology that rapidly increase the complexity of the challenges faced by organizations, this raises the organizational needs of leaders who can direct and develop the efforts of employees with the power they have to achieve organizational goals in building organizations towards high-performance organizations (Harvey \& Brown )

Effective leaders will be able to carry out their functions well, not only shown from the power they have but also shown by the attention of leaders to the welfare and satisfaction of employees towards leaders and improving the quality 
of employees, especially the attitude shown to strengthen the willingness of employees to carry out tasks to achieve organizational goals. Since half a century ago, theory and research on leadership only aimed at autocratic or democratic models, directive or participatory, focused on tasks or people (Bass \& Avolio, 1990).

Subordinate satisfaction shows the attitudes and behavior of subordinates to their leaders. Someone who is satisfied will do positive things and help the leader in achieving organizational goals while if not satisfied will be negative and not help the leader in achieving organizational goals. Transformational leadership will further increase the satisfaction of subordinates because with the influence of three dimensions will lead to feelings of pride, attention, appreciation and encouragement to bring up ideas and creativity which is a means for selfactualization so as to increase subordinate satisfaction (Padsakof et al., 1996 'Bycio et al , 1995 and Koh et al., 1995).

Organizational commitment is an effort to identify yourself and involve yourself in the organization and hope to remain a member of the organization (Robbin, 2000). According to Allen and Mayer (1990) there are three components in commitment, namely: (a) affective (indicating the desire of employees to get involved and identify themselves with the organization because of conformity in the values of the organization). (b) continuance (commitment that arises because there is a concern about the loss of benefits commonly obtained from the organization) (c) normative (commitment that arises because employees feel obliged to stay in the organization). Three components of commitment have been tested by Bass that show a variety of possibilities, transformational leadership may show a strong positive affective relationship because it provides strong feelings and support that encourage employees to remain in the organization, while contingent rewards may be positively related to continuance commitment due to fear against losing benefits if leaving the organization (Brycio et al., 1995).

Performance is the result of work that has been achieved by someone in accordance with the task and its role in accordance with organizational goals associated with certain performance standards of the company where the 
individual works. Therefore the success and performance of a person in a field of work is largely determined by the level of competence, professionalism and commitment to the field in which they are engaged. An organizational commitment shows a person's power in identifying his involvement in a part of the organization (Mowday, Porter \& Steers, 1982 in Vandenberg, 1992). Organizational commitment will create a (sense of belonging) for workers towards the organization.

Research on leadership, commitment and job satisfaction is an interesting topic for further research, because according to Gregson (1992) job satisfaction is the first sign of an organizational commitment.

Whereas according to other studies namely Bateman and Strasser (1984) states that commitment precedes job satisfaction. Therefore research that examines the relationship between the level of job satisfaction in increasing organizational commitment is an interesting topic.Companies that experience a decline in performance can be seen from several sides, namely from the decline in employee performance, namely the absence rate with various reasons and employee turnover rates. As happened to the company PT Alam Kayu Sakti Semarang, the percentage of absence of employees is around $20 \%$ per month and turn over employees $10 \%$ per year.

Decreasing employee performance can be analyzed from the side of the leader, namely the leader is less sensitive to what is desired by subordinates with an example of some employees who have never experienced rotation or mutation for a relatively long period of time in their jobs, giving rise to employee saturation that has an impact on job satisfaction. As is known that leadership that is suitable for subordinates will greatly influence their performance, namely with the existence of job satisfaction for them so that employees in carrying out their work will feel safer and protected. Employees have a performance that exceeds what is supposed to be or above the minimum target of the organization because it already has high morale. It can also be related to job satisfaction, if individuals have happy feelings or positive emotions that are obtained from work experience, which relates to individuals not groups and concerns the past, not the future. 


\section{Formulation of the problem}

Regarding the importance of leadership and job satisfaction for the emergence of commitment and performance of employees, this study seeks to observe what factors support improving performance. This study tries to observe the relationship between leadership, job satisfaction and commitment, which in turn will be able to improve employee performance towards the organization.

Based on the background and formulation of the problem above, the details of the problem formulation that would be answered in this study are:

1. What is the effect of leadership on commitment?

2. What is the effect of job satisfaction on commitment?

3. What is the effect of leadership on employee performance?

4. What is the effect of job satisfaction on employee performance?

5. How does the commitment to employee performance affect?

6. How does commitment become mediation, in relation to the effect of leadership on employee performance?

7. How does commitment become mediation, on the relationship of the effect of job satisfaction on employee performance?

\section{Research purposes}

The objectives of this study are:

1. To analyze the influence of leadership on commitment to the company PT. Alam Kayu Sakti Semarang.

2. To analyze the effect of job satisfaction on commitment to the company PT. Alam Kayu Sakti Semarang. 
3. To analyze the influence of leadership on employee performance in the company PT. Alam Kayu Sakti Semarang.

4. To analyze the effect of job satisfaction on employee performance at the company PT. Alam Kayu Sakti Semarang.

5. To analyze the influence of commitment to employee performance at the company PT. Alam Kayu Sakti Semarang.

6. To analyze the commitment that is mediating or not on the relationship of the influence of leadership on performance in the company PT. Alam Kayu Sakti Semarang.

7. To analyze the commitments that become mediation or not on the relationship of the influence of job satisfaction on performance in the company PT. Alam Kayu Sakti Semarang.

\section{Benefits of research}

The benefits obtained from this study include:

1. For academics, can present information and the results of the empirical presentation of edd-on effects of leadership factors in predicting performance with mediated commitment. So that academics can develop theories of human resources related to the topic of this research.

2. For practitioners, can be taken into consideration for managers, supervisors and people who lead organizations to be able to use leadership patterns because it can improve performance that can affect organizational effectiveness.

3. For the company PT Alam Kayu Sakti Semarang as a material consideration for making policies that still enforce organizational commitment and use leadership patterns that can provide motivators to employees in the hope of fostering job satisfaction that can directly improve employee performance. 
4. It is hoped that it can be used as a contribution to the scientific study for researchers on the development of literature on leadership and job satisfaction associated with commitment to improve performance.

\section{MINDSET}

Company employee performance is expected to always increase to achieve organizational goals. So to improve the performance it is necessary to have existing cooperation organized both cooperation between superiors and subordinates as well as cooperation between subordinates. In this competitive era, there is a demand for good performance of subordinates / employees in the form of behaviors or actions that are relevant to the goals of the organization. Employee performance can be seen from the level of achievement of results in quantity and quality, efficiently and the criteria for the effectiveness of one's work employees associated with organizational goals include cooperation, creative, and innovative.

Leadership that respects the ideas and opinions of employees will give them the freedom to create creativity, and initiative in the effort to complete the work given. A good leader will be able to grow the trust of the employees so that they will be able to carry out their duties well. Encouragement from superiors is expected to be able to generate subordinates encouragement so that they can improve employee performance.

In addition to improving employee performance there is a need for job satisfaction which is a predictor of organizational commitment. Because satisfaction and feeling as part of the demands of life, then feeling satisfied with the task or job, satisfied with the boss and satisfied with colleagues, satisfaction with balanced results and satisfaction with clear rules will affect the feelings of employees and susequently impact on the implementation of activities. 


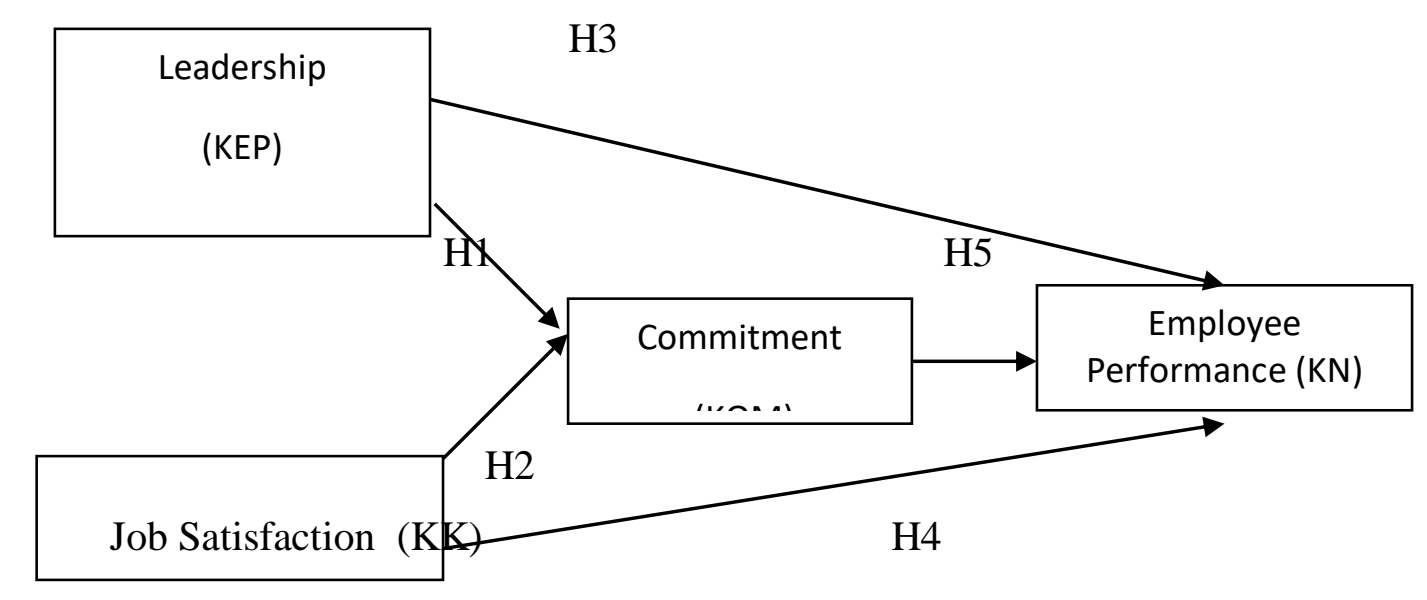

\section{RESEARCH METHODS}

\section{Population and Research Samples}

Population is the total number of objects (units / individuals) whose characteristics are to be expected (Djuwarto and Pangestu Subagyo: 1993). The population in this study is permanent employees of PT. Alam Kayu Sakti (PT. ALKA) Semarang, amounting to 300 people.

Purposive sampling technique, namely sampling that adapts to certain criteria (Cooper \& Emory). The criteria for selected respondents are as follows:

a. Minimum high school education equivalent

b. Male and female sex

c. Work period is over two years

Based on the above criteria, the number of samples can be determined by 109 respondents. The author uses this technique because the population has elements / members who are not proportionally homogeneous and structured, for example having different educational backgrounds. 


\section{Data Type and Sources}

1. Data Type

The data used in this study are grouped into

a. Primary data, namely data originating from the list - the results of the questionnaire.

b. Secondary data, namely documentation data obtained from companies and from other sources.

\section{Data Sources}

Data collection is a systematic and standardized procedure to obtain the required data. The data needed in the study is primary data which is data originating from the original source, obtained directly from the object under study. Primary data in this study were obtained through a list of questions / questionnaires, namely as a tool to collect data in the form of a questionnaire (questionnaire) where the list of questions is quite complete, detailed and systematic about the informations needed from employees of PT. Alam Kayu Sakti Semarang

\section{Research variable}

Based on the formulation of the problem and hypothesis, the variables can be classified as follows:

1. Independent variable $(\mathrm{x})$ consists of:
a. Leadership (X1)
b. Job satisfaction (X2)

2. Mediation variables, namely: Commitment

The variable commitment can be a dependent variable when it is connected between variables of Leadership and Job Satisfaction 
Commitment variables become independent variables when associated with performance variables

a. Dependent variable (Y): employee performance

b. The variable commitment to mediation will be analyzed the effect of the leadership relationship on employee performance.

c. The variable commitment to mediation will be analyzed the effect of the relationship of job satisfaction on employee performance.

\section{Concept Definition}

\section{Leadership}

The meaning and nature of leadership aims to encourage work passion and high employee productivity, in order to achieve maximum organizational goals (H.M.Malayu S.P. Hasibuan, 1990)

The concept of transformational leadership is expressed by B.M Bass (1985) (Hughes et al, 1990). In a study involving military officers and senior officers, Bass gained 3 characteristics of transformational leaders namely Charismatic, Individual Consideration and Intellectual Stimulation.

In research it has been proven that obtaining charisma from subordinates is a transformational leadership success. Transformational leadership with individual consideration will attract differences between employees and act as a mentor to develop subordinates. Transformational leadership with individual consideration will attract careful attention to differences between employees and act as a mentor to develop subordinates with intellectual stimulation able to show employees new ways of solving various problems that arise. From these three dimensions according to Bass (1990) will encourage increased subordinate job satisfaction, organizational performance and encourage subordinates / employees to stay in the organization with increased commitment to the organization. 


\section{Job Satisfaction}

Job satisfaction is as a general attitude and a positive level that someone feels towards his job. (Robbins, 1996) states that there are five factors that support the creation of job satisfaction for employees of an organization, namely (1) mentally challenging work, (2) appropriate rewards; (3) Supporting working conditions, (4) Supporting colleagues; (5) The suitability of personality with work.

\section{Commitment}

Organizational commitment can be seen as a situation where an employee or individual sits with a particular organization and its objectives, and intends to maintain membership in the organization. Thus, high organizational commitment shows the level of ownership of an employee towards the organization that employs it. In Allen and Meyer (1990) proposed three forms of organizational commitment, namely: (1) Affective Commitment, (2) Continuous Commitment; (3) Normative Commitments.

\section{Performance}

Steers (1984) defines performance as the success achieved by individuals in doing their work, where the measure of success achieved can be compared to other individuals. The success achieved by the individual is based on the applicable size and is adjusted to the type of work. According to Miner (1988: 14), performance can be defined as the level of needs of each individual, as hope for the work he does. Miner gave two variables that determine one's work performance, as follows:

a. Variables resulting from organizational behavior include behavior and attitudes of individuals, involvement in work, and work participation.

b. Variables of results that have been achieved for a performance, which includes four performance dimensions consisting of:

1) Quality of output (quality of output)

2) Output quantity (quantity of output)

3) Working time (time of output) 
4) Cooperation with other colleagues (cooperation with other's work)

The four dimensions are interrelated with each other, for example good cooperation between colleagues is directly influenced by the quality and quantity of output of each individual.

\section{Data Analysis Technique}

\section{Validity Test}

Testing the validity of using the technique of factor analysis (construct Validity), namely to test whether the items in question or indicator used can confirm a factor or construct or variable. If each question is a variable indicator then it will have a high value of loading factor above 0.4. As an item selection criterion based on factor analysis, it is usually used to limit the sample trust level or the Kaiser Meyer-Olkin Measure of Sampling Edequacy (KMO) value> 0.60. If the KMO value is above 0.60 and loading factor> 0.4 , then the sample in the study is considered sufficiently valid for further analysis.

\section{Reliability test}

Reliability test is a reliability test that aims to find out how far a measuring instrument can be trusted. Reliability is related to the estimation of the extent to which a measuring instrument is consistent if measurements are made repeatedly on different samples. If a measuring instrument is used repeatedly and the measurement results obtained are relatively consistent, the measuring instrument is considered reliable (reliable). Conversely, if a measuring instrument is used repeatedly and the measurement results obtained are not consistent then the measuring instrument is considered not reliable.

In this test, the reliability test is done using the Cronbach alpha coefficient. The cronbach alpha coefficient calculation utilizes SPSS help and the critical limit for the cronbach alpha value to indicate a reliable questionnaire is 0.60 . With the 
cronbach alpha coefficient $>0.60$ is an indicator that the questionnaire is reliable / reliable.

\section{Model Testing}

1. Multiple Regression Analysis

This regression aims to determine the effect of independent variables on the dependent variable. To test the effect of leadership on employee performance through mediation Organizational commitment, two stages of regression are carried out with the following formula:

$$
\begin{gathered}
\mathrm{KOM}=\mathrm{a}+\mathrm{b} 1 \mathrm{KEP}+\mathrm{b} 2 \mathrm{KK}+\mathrm{e} \\
\mathrm{KN}=\mathrm{a}+\mathrm{b} 3 \mathrm{KEP}+\mathrm{b} 4 \mathrm{KK}+\mathrm{b} 5 \mathrm{KOM}+\mathrm{e}
\end{gathered}
$$

Keterangan :

$\begin{array}{ll}\text { KOM } & =\text { Commitment } \\ \mathrm{KN} & =\text { Performance } \\ \mathrm{a} & =\text { Constant } \\ \mathrm{b} 1-\mathrm{b} 3 & =\text { Regression coefficient } \\ \mathrm{KEP} & =\text { Leadership } \\ \mathrm{KK} & =\text { Job Satisfaction } \\ \mathrm{E} & =\text { Error or annoying error }\end{array}$

2. The coefficient of determination (R Square)

The coefficient of determination ( $\mathrm{R}$ Square) is used to see the ability of independent variables to explain the dependent variable and proportion of the dependent variable explained by variations in the independent variables. If the $\mathrm{R}^{2}$ obtained from the calculation results shows the greater (close to one), it can be said that the contribution of the dependent variable is getting bigger. This means that the model used is getting bigger to explain the dependent variable. 
Conversely, if the $\mathrm{R}^{2}$ shows smaller, this means that the model used is getting weaker to explain the variation of the dependent variable. In general it is said that the magnitude of the multiple determination coefficient $\left(\mathrm{R}^{2}\right)$ is between 1 or $0 \leq$ $\mathrm{R}^{2} \leq 1$

\section{Hypothesis Testing}

Hypothesis testing is done to test the significance of the influence of the independent variable namely Leadership and Job Satisfaction on the dependent variable, namely Performance and mediation Organizational commitment carried out through:

\section{Partial Test ( $\mathrm{t}$ Test $)$}

The $t$ test basically shows how far the influence of one independent variable individually in explaining the variation of the dependent variable (Ghozali, 2002: 44). Testing through the $\mathrm{t}$ test is done by comparing $\mathrm{t}$ count ( $\mathrm{t}$ count) with $\mathrm{t}$ table $(\mathrm{t}$ table). $\mathrm{t}$ table at $\alpha=5 \%$. The testing criteria are if $\mathrm{t}$ count $>\mathrm{t}$ table, then the hypothesis is accepted, meaning that there is a significant influence with the positive direction between the two tested variables, on the contrary if $t$ count $<\mathrm{t}$ table, then the hypothesis is rejected, meaning there is no significant influence with positive direction between two variables tested.

\section{Mediating Test}

Mediating or intervening is an intermediate variable that serves to mediate the relationship between the independent variable and the dependent variable. To test the effect of mediating variables, the path analysis method is used. Path analysis is an extension of regression analysis that is used to estimate the relationship between variables (causal models) that have been predetermined based on theory.

Pathway analysis alone cannot determine causal relationships and cannot be used as a substitute for researchers to see the relationship between relationships. 
What can be done by path analysis is to determine the pattern of relationships between three or more variables and cannot be used to confirm or reject the imaginary cohesive hypothesis.

Path diagrams provide explicit causality between variables based on theory. Arrows show relationships between variables. In describing the path diagram that needs to be considered is the one-headed arrow is a regression relationship. Direct relationships occur if one variable affects another variable without a third variable that mediates (intervening) the relationship between the two variables. In each independent variable there will be an arrow that leads to this variable (mediation) and this serves to explain the number of variances that cannot be explained by other variables.

The path coefficient is the standardized regression coefficient. Path coefficients are calculated by making structural equations namely regression equations that show prioritized relationships (Ghozali, 2002, 160-161).

The following path analysis can be done:

Total leadership effect $=(\mathrm{p} 3)+(\mathrm{p} 1)(\mathrm{p} 5)$

Total job satisfaction effect $=(\mathrm{p} 4)+(\mathrm{p} 2)(\mathrm{p} 5)$

Total commitment effect $=(\mathrm{p} 5)$

\section{RESEARCH RESULT}

\section{Test of Hypothesis 1}

Effect of Leadership on Organizational Commitment

The direct influence of leadership variables on organizational commitment variables can be described in the following research regression model. 
Tabel 1

Coefficients (a)

\begin{tabular}{|r|r|r|r|r|r|r|}
\hline & & $\begin{array}{c}\text { Unstandardi } \\
\text { zed } \\
\text { Coefficients }\end{array}$ & & $\begin{array}{c}\text { Standardized } \\
\text { Coefficients }\end{array}$ & $\mathrm{t}$ & \multicolumn{1}{c|}{ Sig. } \\
\hline Model & & $\mathrm{B}$ & Std. Error & Beta & & \\
\hline 1 & (Constant) & 1.277 & .506 & & 2.524 & .013 \\
\hline & LEADERSHIP & .276 & .087 & .279 & 3.171 & .002 \\
\hline & SATISFACTION & .366 & .106 & .305 & 3.470 & .001 \\
\hline
\end{tabular}

a Dependent Variable : COMMITMENT

Source: primary data processed

From the table above it can be seen that the leadership regression coefficient $($ Beta $=0.279)$ has a positive influence on the variable organizational commitment, meaning that the higher the influence of leadership, the higher the commitment of the employees of PT. Alam Kayu Sakti Semarang. ( $p=0.002$ $<0.05)$, so hypothesis 1 is accepted.

The results of the regression analysis in table 1 provide support for the proposed hypothesis, namely leadership has a positive and significant effect on the organizational commitment of employees of PT. Alam Kayu Sakti Semarang ( $\mathrm{p}=0.02<0.05)$, so hypothesis 1 is accepted .

\section{Test of Hypothesis 2}

Effect of Job Satisfaction on Organizational Commitments

From table 1 above it can be seen that the satisfaction regression coefficient $($ Beta $=0.305)$ has a positive influence on the organizational commitment variable of PT. Alam Kayu Sakti Semarang. 
The results of the regression analysis in table 1 provide support for the proposed hypothesis, namely job satisfaction has a positive and significant effect on the organizational commitment of employees of PT. Alam Kayu Sakti Semarang $(\alpha=$ $0.001<0.05)$, so hypothesis 2 is accepted.

3. Test of Hypothesis 3

Effect of Leadership on Employee Performance

The direct effect of leadership variables on employee performance variables can be described in the following research regression model

Tabel 2

\section{Coefficients}

\begin{tabular}{|r|r|c|c|c|c|c|}
\hline & & $\begin{array}{c}\text { Unstandardized } \\
\text { Coefficients }\end{array}$ & & $\begin{array}{c}\text { Standardized } \\
\text { Coefficients }\end{array}$ & $\mathrm{t}$ & Sig. \\
\hline Model & & $\mathrm{B}$ & Std. Error & Beta & & \\
\hline 1 & (Constant) & .979 & .312 & & 3.132 & .002 \\
\hline & LEADERSHIP & .126 & .055 & .172 & 2.315 & .023 \\
\hline & SATISFACTION & .330 & .067 & .370 & 4.935 & .000 \\
\hline & COMMITMENT & .296 & .058 & .398 & 5.076 & .000 \\
\hline
\end{tabular}

a Dependent Variable : PERFORMANCE

Source: primary data processed

From table 2 above it can be seen that the leadership regression coefficient $($ Beta $=0.172)$ has a positive influence on the variable performance of employees of PT. Alam Kayu Sakti Semarang. The results of the regression analysis in table 2 provide support for the proposed hypothesis, namely leadership has a positive and significant effect on the performance of employees of PT. Alam Kayu Sakti Semarang $(\alpha=0.023<0.05)$, so hypothesis 3 is accepted. 


\section{Test of Hypothesis 4}

Effect of Satisfaction on Employee Performance

From table 2 above, it can be seen that the satisfaction regression coefficient $($ Beta $=0.370)$ has a positive influence on the performance variable of PT. Alam Kayu Sakti Semarang.

The results of the regression analysis in table 2 provide support for the proposed hypothesis, namely job satisfaction has a significant positive effect on the performance of employees of PT. Alam Kayu Sakti Semarang $(\alpha=0,000$ $<0,05)$, so hypothesis 4 is accepted.

\section{Test of Hypothesis 5}

Effect of Commitments on Employee Performance

From table 2 above it can be seen that the commitment regression coefficient $($ Beta $=0.398)$ has a positive influence on the employee performance variables of PT. Alam Kayu Sakti Semarang, so if the opposite happens.

The results of the regression analysis in table 2 provide support for the proposed hypothesis, namely organizational commitment has a significant positive effect on the performance of employees of PT. Alam Kayu Sakti Semarang $(\alpha=0,000>0.05)$, so hypothesis 5 is accepted

\section{Test of Hypothesis 6}

Effect of Leadership on Performance with Mediated Organizational Commitments

To test hypothesis 6 which is testing the mediating effect or testing the effect of leadership on employee performance mediated by organizational 
commitment, it is done by comparing the results of the standardized coefficients directly with indirectly.

To do the test using path analysis (path analysis) by comparing the direct influence of leadership on performance with indirect effects through organizational commitment as a mediating variable.

Testing of hypothesis 6 is done with the following steps:

\section{Direct Effect}

Leadership Against Performance $\quad=0,172$

Indirect Effect

KEP to KOM to $\mathrm{KN}=0,279 * 0,398=0,1110$

So that it can be concluded from the results of the above testing, based on the provisions where indirect effects are smaller than direct effects, it is stated that organizational commitment is not an intervening or mediating variable that is unable to explain the indirect influence of leadership on performance, so hypothesis 6 which reads: leadership has a positive effect on the performance of employees of PT. Alam Kayu Sakti Semarang with mediated by organizational commitment is not acceptable

\section{Test of Hypothesis 7}

Effect of Job Satisfaction on Performance with Mediated Organizational Commitments

To test hypothesis 7 which is testing the mediating effect or testing the effect of job satisfaction on employee performance mediated by organizational commitment, it is done by comparing the standardized coefficients directly and indirectly. 
To do the test using path analysis (path analysis) by comparing the direct effect of job satisfaction on performance with indirect effects through organizational commitment as a mediating variable.

Testing of hypothesis 7 is done with the following steps:

\section{Direct Effect}

Job Satisfaction Against Performance $=0,370$

Indirect Effect

KK to $\mathrm{KOM}$ to $\mathrm{KN}=0,305 * 0,398=0,1214$

So that it can be concluded from the results of the above test, based on the provisions where indirect effects are smaller than direct influences, it is stated that organizational commitment is not an intervening or mediating variable that is unable to explain the indirect influence of work on performance, so the hypothesis 7 which reads: work decision has a positive effect on the performance of employees of PT. Alam Kayu Sakti Semarang with mediated by organizational commitment is not acceptable

From the results of the regression analysis above, the contribution of independent variables to the dependent variable can be stated in the graphic model as follows: 
Picture : Regression graphic model

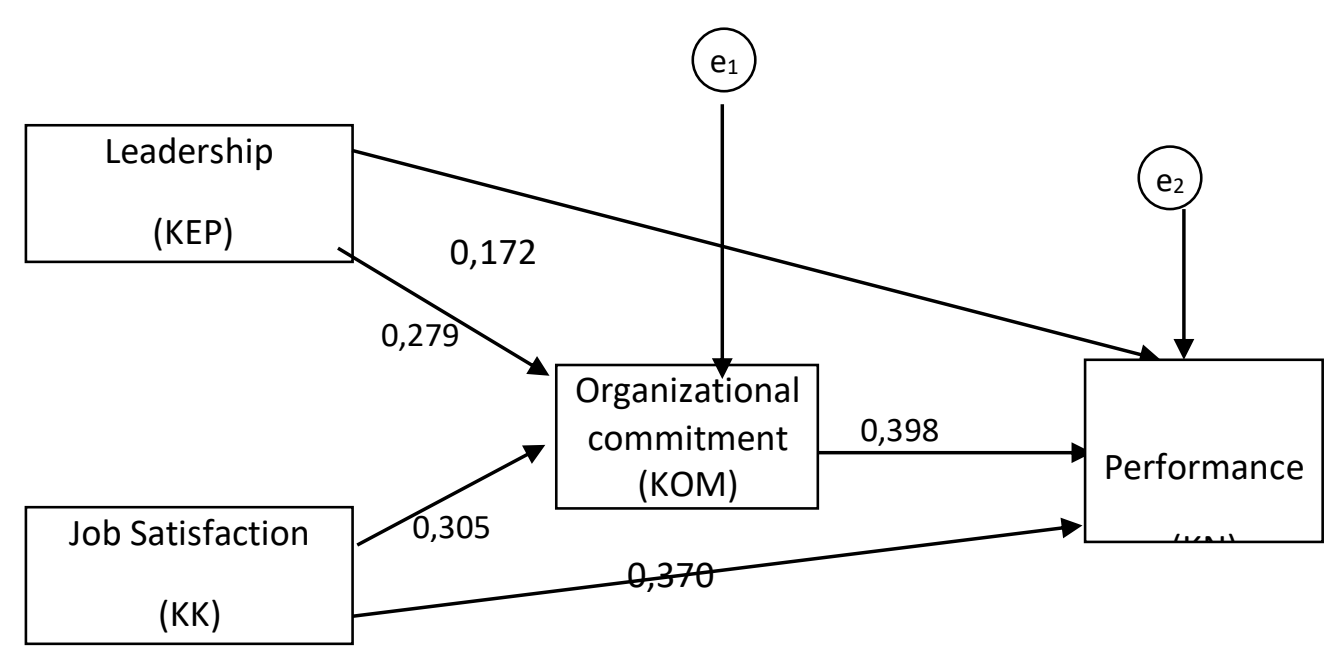

\section{DISCUSSION}

From the results of the partial test and the overall test model the results obtained that leadership and job satisfaction have a positive and significant effect on employee performance mediated by organizational commitment. Therefore, the factors of leadership, job satisfaction and organizational commitment at PT. Alam Kayu Sakti Semarang really needs to get the attention of policy makers / decisions, because increasing leadership, job satisfaction and organizational commitment is expected by an organization, where more and more employees have high performance. then the overall performance of the organization will be higher so it is expected that the organization concerned will be able to continue to progress and develop..

The results of this study are consistent with previous researchers conducted by Yustiani, Utai Dian (2004) which states that job satisfaction has a significant positive effect on organizational commitment and job satisfaction has a significant positive effect on employee performance

Other research conducted by Murdoko (2007) provides results that Leadership has a positive and but not significant effect on organizational 
commitment or is not proven to be true. Organizational commitment has a positive and significant effect on performance, such conditions can be interpreted that when employees of the Central Java Province Plantation Office have high organizational commitment, it will have a positive impact on improving employee performance. Leadership has a positive but not significant effect on performance, so that it can be interpreted that the aligned leadership of the Central Java Provincial Plantation Office has not been able to implement the right leadership pattern in accordance with the existing situation and working environment, thus affecting the performance of employees and not optimal.

From the statistical findings and supported by empirical data, the managerial implications of the findings of this study for PT. Alam Kayu Sakti Semarang, including:

1. Based on empirical results it can be seen that leadership has a positive influence on commitment. The better leadership, it will increase employee commitment. Of the 109 respondents there were $11 \%$ of respondents who were unhappy with leadership now, where leaders sometimes were unable to understand their subordinates with views conveyed by subordinates, leaders always viewed subordinates in doing their work there were always shortcomings. in decision making to solve problems does not involve subordinates how to take the best solution in new ways. Such conditions can lead to lack of trust in subordinates of the leadership ability.

2. Job satisfaction has a positive influence on commitment. The more satisfied the employee will increase employee commitment. From 109 employees of PT. Alam Kayu Sakti Semarang which was used as the respondent there were still employees who were not satisfied in the work, namely:

As many as $5.5 \%$ of respondents assume that not all subordinates have the opportunity, or are given the opportunity by the leadership to become leaders in their community / team. As many as $6.4 \%$ of respondents think that not all subordinates have the ability to make decisions, because there are fears of an error that has an impact on its performance. As many as $5.5 \%$ of respondents think that there is a policy from the company that is not 
implemented in practice, which is felt by some subordinates, thus impacting the decline in performance. Decreased performance of subordinates can be seen from the level of attendance, which is a medium to heavy scale, that is, from employee turnover

3. Leadership has a positive influence on performance

To create a conducive leadership a leader must be able to understand his subordinates with views conveyed by subordinates, leaders always see that subordinates in doing their work are always lacking, Leaders are less capable of solving problems, where decision making to solve problems does not involve subordinates how the best solution is taken in new ways. Such conditions can lead to lack of trust in subordinates of the leadership ability. With these measurements, it is expected that it will have a positive impact on performance.

4. Job satisfaction has a positive influence on performance. To improve employee performance, the company does not forget to provide a factor of employee job satisfaction. In this research, employees are not satisfied with: not all subordinates get the opportunity, or are given the opportunity by the Leader to be a leader in their community / team; Not all subordinates have the ability to make decisions, because there are fears of an error that has an impact on its performance. there is a policy from the company that is not applied in practice, which is felt by some subordinates, thus impacting the decline in performance. Decreased performance of subordinates can be seen from the level of attendance, which is a medium to heavy scale, that is, from employee turnover

5. Commitment has a positive influence on performance

The more employees have a high commitment to the company, then it will have a positive impact on improving employee performance. For this reason, companies must be able to provide the comfort of their employees at work so that they are reluctant to leave work after working for the company PT. Alam Kayu Sakti Semarang .Berdasarkan hasil empiris ditemukan bahwa komitmen bukan sebagai mediasi antara kepemimpinan terhadap kinerja. 
Karena nilai secara langsung (kepemimpinan ke kinerja) lebih besar dibandingkan nilai secara tidak langsung yaitu Kepemimpinan melalui komitmen hingga tercipta kinerja karyawan.

6. Based on empirical results it is found that commitment is not as a mediation between work headaches and performance. Because the value directly (job satisfaction to performance) is greater than the value indirectly namely job satisfaction through commitment to create employee performance.

7. In this study job satisfaction is the dominant factor in influencing organizational commitment followed by leadership. Where job satisfaction is affected through work factors that are mentally challenging, appropriate rewards; supportive working conditions, supportive colleagues; and the suitability of personality with work.

8. In addition, empirical evidence can be found that organizational commitment is the dominant factor in influencing performance followed by job satisfaction and leadership. Where organizational commitment is influenced by factors of affective commitment, Continuous commitment; and normative commitment.

\section{CONCLUSION}

From the results that have been studied at PT. Alam Kayu Sakti Semarang, then conclusions can be drawn as follows:

1. This study can prove leadership has a positive effect on organizational commitment. This is in accordance with his theory Bass (1990).

2. This study can prove job satisfaction has a positive effect on organizational commitment. This is according to Johlke's (2000) study.

3. This study can prove leadership has a positive effect on performance. This is in accordance with his theory Bass (1990).

4. This research can prove job satisfaction has a positive effect on performance. This is in accordance with his theory Robins (1996). 
5. This research proves organizational commitment has a positive effect on performance. This is in accordance with the study of Johlke et al (2000).

6. This research does not prove that organizational commitment mediates the influence of leadership on performance. This is in accordance with Tri Murdoko's research (2007).

7. This study does not prove that organizational commitment mediates on the effect of job satisfaction on performance. This is consistent with Yustiani's research, Utai Dian (2005).

\section{SUGGESTION}

By paying attention to the state of the company and from the conclusions above, the authors try to provide suggestions that can be found for the company's progress in the future, as follows:

1. The company is expected to increase job satisfaction where job satisfaction is the most dominant factor in influencing organizational commitment. Thus for the new leadership, a leader is expected to inspire his subordinates and can make subordinates think about problem solving in new ways.

2. It is better if the company is expected to maintain the factor of organizational commitment, because organizational commitment is the most dominant factor in influencing performance. Organizational commitment can be improved through: the attitude of employees as part of the company, employees are reluctant to leave the company, employees are obliged to work for this company.

\section{LIMITATIONS OF RESEARCH}

The research that the authors did has several limitations, including:

1. Limitations of research samples as one of the main data sources, which are limited to employees of PT. Alam Kayu Sakti Semarang. 
2. In this study, the number of operational variables in the model is limited, namely the variables of leadership, job satisfaction, organizational commitment and employee performance, although theoretically and empirically there are still other variables that are better able to explain the indirect influence of leadership and job satisfaction on employee performance with mediation of organizational commitments which include: motivation, work discipline, work environment, job promotion and so on.

\section{THE RESEARCH WILL COME}

1. It is recommended that research be carried out not only for permanent employees based on predetermined criteria, but also by researching all permanent employees of PT. Alam Kayu Sakti Semarang to get a clearer phenomenon in the company PT. Alam Kayu Sakti Semarang.

2. The selection of indicators should be more numerous and vary according to the conditions existing in the object of the research concerned.

\section{B I B L I O G R A P H Y}

AA. Anwar Prabu Mangkunegoro, drs. MSi, PSi. Manajemen Sumber Daya Manusia, PT. Remaja Rosdakarya, Bandung, 2000

AA. Rachmat MZ, SE. Manajemen Suatu Pengantar, CV. Remaja Karya, Bandung, 1983.

Aburazak,Drs. Modul Kepemimpinan Kerja, 1997

Hadi, Sutrisno, Ststistik II, Andi offset Yogyakarta, 1987

Hani Handoko, , edisi ke tiga, BPFE, Yogyakarta, 1995 Manajemen Personalia dan Sumber Daya Manusia 
Nainggolan, Pembinaan Pegawai Negeri Sipil, Cetakan ke Empat, PT. Naltu, 1983.

Hasibuan MSP. Organisasi dan Motivasi : Dasar Peningkatan Produktivitas, Penerbit Bumi Aksara, Jakarta, 1996.

Imam Ghozali, Aplikasi Analisis Multivariate dengan Program SPSS, Edisi ke 3, Badan Penerbit Universitas Diponegoro, Semarang, 2005

John Supriyanto, Drs. MM. Tk. Agung M. Harsiwi, SE, MSi, Prakosa Hadi, Drs. MBA., Perilaku Organisasi, STIE YKPN, Yogyakarta, 2003

Luthan F ( 1995 ) Organization Behavior, 8 th edition New York The MC Graw Hall Co, Inc Moudy, RW. RM Noe SR Premeux 1999, HumanResourses Management 7 th, Edition New Jersey, Printice Hall Inc.

Michael Armstrong, Managing People, alih bahasa Ramelan dan Dwi Prabaningtyas, PT. Gramedia, Jakarta, 2002.

Mitchel, CE dan SpectorPE ( 1982 ) Couse Of Employee Turnover, A Test Of the Mobley, Greffeth, Hand and MeglinoModel, Journal Of Applied Psycology 67, 53,59.

Miner, John B, Organizational Behavior, Perfomance \& Productivity, State University, New York at Buffallo, 1988

Murdoko, Tri, 2007, Pengaruh Kepemimpinan Dan Motivasi Terhadap Kinerja Pegawai Dinas Perkebunan Propinsi Jawa Tengah Dengan Mediasi Komitmen Organisasional, Tesis Stikubank, Tidak dipublikasikan

Mowdey RT, The Measure of Organizational Commitment,

Journal of Vacation Behavior, 1982 
Nawawi H. Manajemen Sumber Daya Manusia,Cetakan ke Empat,Yogyakarta, Penerbit Gajah Mada University Press, 2001

Stephen P. Robbins, Perilaku Organisasi, jilid 1, Edisi 9,Printice Hall, PT. Indeks Kel. Gramedia

Porter, LW Steers, R M, Mowday, R T ( 1983 ) Organizational Commitment Job Satisfaction, and Turnover Among Psychiatric Technicians, Journal of Applied Psycology.

Pola Kerja Terpadu, Lembaga Administrasi Negara Republik Indonsia, Perilaku Kepemimpinan, 1997.

Suwarno Martoatmodjo, Drs. MSi. Teori Motivasi, Undip FE,1985

Steers RM, dan Porter, LW, 1983, Motivation and Work Behavior, Boston, MC Graw-Hill Book Co.

Timpe, A Dale, Kepemimpinan, Seni Ilmu dan Seni Bisnis, PT. Elex Media Komputindo, Jakarta, 1991

Umar, Husain, Riset Sumber Daya Manusia Dalam Organisasi, PT. Gramedia, Pustaka Utama, Jakarta, 1999

W. Gulo, Metodologi Penelitian, Cetakan ke Dua, Penerbit PT Gramedia Widiasarana Indonesia , Jakarta, 2003

Wahyu Sumidjo, Kepemimpinan dan Motivasi, Cet. keIII, Ghalia Indonesia, Jakarta, 2002

Wexley, Keneth N, Yukl, Gary A, Leadership in Organizations second edition , Printice Hall International Inc Englewood Cliffs, New Jersey. 
Yustiani, Utai Dian, 2005, “Analisa Pengaruh Kepuasan Kerja, Keadilan Kompensasi Terhadap Kinerja Karyawan Dengan Komitmen Organisasi Sebagai Intervening", Tesis Universitas Diponegoro Semarang, Tidak Dipublikasikan. 
Majalah Ilmiah Solusi

Vol. 17, No. 3 Juli 2019

ISSN : 1412-5331

Halaman ini sengaja dikosongkan 